\title{
An empirical study of what institutions of higher education in the UK consider to be their corporate social responsibility
}

\author{
S. O. Idowu \\ London Metropolitan University, UK
}

\begin{abstract}
The field of corporate social responsibility (CSR) is relatively new when compared with other fields. It was in the 1980s that corporate entities around the world started to generate increasing interest in CSR, as we currently know it. However, a search of the literature has revealed that researchers in the field have tended to concentrate more efforts on the CSR of profit seeking corporate entities. Unfortunately this does not appear to be the case when it comes to the CSR of not-for-profit (NFP) corporate entities such as educational establishments (schools, colleges and universities), hospitals, the police, the armed forces, the fire services and other social entities that play equally important roles in modern economies. Do these NFP organisations consider that they have a role to play in CSR as is perceived by corporate stakeholders in the $21^{\text {st }}$ century? If they do, then do they play these roles as effectively as they should? How do these entity stakeholders perceive the contributions they make to society's well-being? These and other pertinent questions are what this research study seeks to find answers to.

The study looks at what the UK's institutions of higher education consider to be their corporate social responsibilities and how they have absorbed these responsibilities into what they do in order to discharge these responsibilities to local, national and international communities. The research shows that most institutions of higher education in the UK are conscious that they owe some responsibility to all their stakeholders and are striving to demonstrate this awareness in various ways.
\end{abstract}

Keywords: social responsibility, not-for-profit organisations, higher education institutions, environment, stakeholders, universities, UK, sustainability. 


\section{Introduction}

Corporate entities of whatever shape or form (profit motive or not-for-profit) aspire to be successful in whatever they do. Success can come about through several avenues. In recent times, corporate entities around the world have come to realise that success can be achieved when they are perceived by their stakeholders as being socially responsible; these stakeholders tend to warm to what the entities do or stand for; which consequently makes a big difference in terms of whether or not they achieve their strategic objectives. A socially responsible corporate entity takes cognisance of the impact of its actions on its communities, its stakeholders and the environment when formulating its corporate objectives and in its decision making process. It strives at all times to either minimise or totally remove the adverse effects of its activities on the environment, employees, business contacts group, suppliers of funds and credits, governments and other affected members of society. Corporate entities around the world now consider that being socially responsible is very 'trendy' indeed!

The activities of several non-governmental organisations (NGOs) (also known as pressure groups) can be argued to have played a catalytic role in the emergence of the field of corporate social responsibility. These NGOs try to police different aspects of corporate and governmental behaviours in both the developed and less developed countries of the world in order to ensure that these behaviours do not fall short of acceptable standards. International organisations such as Green Peace, Amnesty International, Friends of the Earth, World Wildlife Fund are a few of such organisations. In addition, business associations such as the World Council on Sustainable Development, Business in the Community (BitC), CSR Europe and several others are propagating various CSR related activities and events to increase corporate and societal awareness of what the field entails and how beneficial its inculcation into business operations would be on the environment, their stakeholders and the world at large. The United Nations and many of its arms have been very active in the area of Sustainable Development; over the last few years several United Nations' sponsored related conferences have been held, the Bali Climate Change Conference in December 2007 is a recent example. Several governments across the world are also propagating CSR. The present UK government continues to portray itself as an enthusiastic advocate of CSR.

Universities across the world because of the societal leadership role they have through their research and particularly their teaching are in a unique position to make a difference in the practice and acceptance of CSR by tomorrow's leaders. This therefore explains why a study on universities involvements with CSR will be of interest to us all.

The higher education sector in the UK has been experiencing a transformation phase of late. Institutions of higher education are gradually becoming more selfautonomous, students are now perceived as clients, the word 'competition' was of no significance in the industry before now, there was no distinction between local and overseas students vis-à-vis the fees they paid until the 1980s and profit or surplus was not one of the variables used previously to measure success or 
performance; as long as the objectives of the institution concerned were achieved in terms of efficiency, effectiveness and value for money. All these are changing in UK's higher education institutions and it appears that nothing can be taken for granted anymore! The industry will become even more competitive and selfregulated as time goes by.

The system of higher education has now been internationalised according to the International Finance Corporation [18], which argues that in 2003 about $2 \%$ of the world's university student population of $100 \mathrm{~m}$ were studying outside their home countries. It also notes that there has been an annual growth of 7\% in the market since the late 1990s with a current annual fee income of $\$ 30$ billion. A fee income of this magnitude signifies the enormity of the market. If institutions of higher education in the UK wish to continue to attract foreign students who are prepared to pay higher discriminatory fees in order to enable them to take a reasonable portion of that total annual fee income, in addition to providing good quality services (which they are noted for) they must be seen to be socially responsible by this stakeholder group (clients) and other stakeholder groups related to them e.g. governments of their home countries, prospective employers and loan providers such as the International Education Finance Corporation (an arm of the World Bank which provides loans to international students).

This paper is constructed as follows: first, it reviews the literature on the corporate social responsibility of profit seeking corporate entities and the few available ones on not-for-profit corporate entities with a description of some of the previous studies undertaken in the area. The empirical work undertaken for the study is presented next, including details of the method used and its findings. Finally, the implications of the paper are considered with the author's concluding remarks.

\section{Reviewing the literature on CSR as it applies to corporate entities including universities}

The concept of corporate social responsibility is not a totally new one as noted by several academic researchers in the literature; the British Institute of Management noted that the use of CSR has been on the corporate scene in the UK for as far back as 1947, Crowther [5], who argues that CSR has been in existence in Britain since the Industrial Revolution of the $18^{\text {th }}$ century, Maltby [22], who argues that it has been practiced proactively by a number of British manufacturing companies; especially Sheffield steelmakers during the beginning of the $20^{\text {th }}$ century and Norris and O'Dwyer [24] who summed it all up when they argued that 'the concept has received much attention in the past but this has tended to wax and wane; what we are now witnessing is only a resurgence of interest in the field of corporate social responsibility'.

Academic researchers, in an attempt to understand the factors that have helped to heighten recent interests in the field of corporate social responsibility as we presently understand it; have postulated a number of theories which they have used to support their arguments and formalise the results of their studies. These are decision usefulness theory (which argues that investors find the social 
information disclosed by corporate entities helpful in their decision making exercise) see for example Spicer [27], Buzby and Falk [2], Belkaoui [1], Mahapatra [21], agency theory (which views the relationship that subsists between the managers and owners of a corporate entity as that of agents and principals) see for example Jensen and Meckling [19], stakeholder theory (which assumes that in order for an entity to generate sustainable wealth over a long period of time, good relationships must exist between that entity and its critical stakeholders) see for example Carroll [3], Freeman [8], Clarkson [4] (who distinguishes between two classes of stakeholders namely; primary and secondary stakeholders), sustainable development theory (which argues that the future of mankind lies in his ability to build sustainable business enterprises and an economic reality which connects industry, society and the environment) see Hart [12], Senge and Carstedt [26] and Ricart et al [25], social and political theory (which describes society as operating under 'a series of social contracts between members of society and society itself) Gray et al [11] and finally legitimacy theory (which postulates that 'the actions taken by an entity are assumed to be desirable, proper or appropriate within some socially constructed system of norms, values, beliefs and definitions') Lindblom [20], Suchman [28]) and Gray et al [10].

Vogl [30] takes a slightly different approach to the theories mentioned above. $\mathrm{He}$ argues that four factors can be recognised as contributing to the recent trends in corporate entities around the world embarking on socially responsible behaviours. These factors he argues; are tightening regulatory pressures, changing demographics, pressure from non-governmental organisations and the increased necessity for greater transparency.

Prior to the 1970s, the maximisation of the shareholders' wealth was assumed to be the singular objective of the firm. Thus Friedman [9] argues that managers are expected to conduct the business of the enterprise in accordance with the owners' or shareholders' desire, which generally will be to make as much money as possible whilst conforming to the basic rules of society which are embodied in local laws and customs. However, Elkington [6] argues that this cannot possibly be the case as shareholders only belong to one of the many stakeholder groups of a business entity. The objectives are in actual fact three-fold argues Elkington, namely to create economic value (which agrees with Friedman's argument), ecological and social values for all concerned (that is all affected stakeholders). It should be noted that there is a twenty-seven year gap between their times. Friedman's argument was not wrong. It was only based on what were then the accepted standards. Elkington's argument was equally not incorrect, by 1997 society had become more developed, more sophisticated and better informed, corporate entities too had recognised that they operate in a multi-stakeholder world and that they must be seen to take on board the needs of all their stakeholders. They can no longer continue to meet the needs of just one stakeholder group at the expense of the other stakeholder groups; a balance needs to be struck in meeting the needs of them all.

The issue of sustainability (which is the bigger umbrella under which CSR falls) in higher education has become a big debate and consequently a research 
based area for academics in various institutions of higher education around the globe see for example van Weenen [29] whose research looks at the experiences of different universities around the world during the process of integrating sustainable development in their activities including the university of Amsterdam, The Netherlands, Noeke [23] whose research in Germany focuses on the establishment of an environmental management system at the University of Paderborn, Wright [32] whose research in Canada focuses on a set of major national and international frameworks for sustainability in higher education through the use of declarations, Wals and Jickling [31] (who were based in The Netherlands and Canada respectively) their research explores both the overarching goals and process of higher education from an emancipatory view and with regard to sustainability, Fien [7] whose research in Australia explores issues related to the choice of goals and approaches for advancing sustainability in higher education and Holt [15] whose research examines the values, actions and attitudes of a group of students as they enter and leave a business school at Middlesex university UK. This has come about as a result of different factors. Firstly, societies are becoming increasingly conscious that man's natural resources nature has will not last forever; in fact some species are gradually becoming extinct at an alarming rate (Wals and Jickling [31]) and if nothing is done at the rate some of these resources are being used or wasted they will become too scarce when the next generation occupy this planet. Secondly, international organisations for example the United Nations and its various arms are organising conferences and conventions on Sustainable Development and Climate Change to draw the attention of world leaders in the fields of politics, education, business and others (who have the power to influence behaviours); that actions need to be taken urgently to alleviate future problems in this area; see for example Agenda 21 in Rio of 1992, the Kyoto Protocol of December 1997, Bali Climate Change Convention 2007 and similar actions which have been taken. Finally, it is apparent that educators in higher education institutions are in fortunate and privileged position because they have the opportunity and power to influence the thoughts, future actions and behaviours of tomorrow's managers and leaders today! It therefore makes sense to start the 'indoctrination' of these future leaders about these issues right from these institutions of learning.

\section{Corporate social responsibility and sustainable development}

CSR is an all embracing word that covers a wide variety of activities. Some authors have described the field as being about corporate entities' ability to 'in addition to making a profit, also helping to solve some social problems regardless of whether or not they have been responsible for creating those problems in the first place; even if there is potential profits or gains either in the short-run or long-run' Holmes [14]. The field is about what corporate entities are doing to contribute positively to what is going on in the world around them. It is now a common practice for organisations in certain industries and in the more industrialised parts of the world to install environmentally friendly machinery, 
use recyclable raw materials, rehabilitate sites which may have been damaged by their previous actions, treat employees equally regardless of sex, race, religion, disability etc, respect the conventions on human rights, disassociate themselves from suppliers of child labour products, be engaged in sustainable development, make donations for charitable purposes and other socially responsible actions which modern corporations embark on in order to demonstrate that being responsible is as important to them as doing well Idowu and Papasolomou [17].

Sustainable development is an important aspect of CSR and corporate entities (regardless of whether profit oriented or not profit oriented) which aspire to be perceived by their stakeholders as being socially responsible must be interested in sustainability and sustainable development. In an attempt to encourage institutions of higher education to be involved in sustainable development, a new initiative was established in the summer of 2000 funded by the UK Higher Education Funding Councils in England, Scotland, Wales and Northern Ireland and led by the Forum for the Future called the Higher Education Partnership for Sustainability (HEPS). HEPS is made up of 18 universities and colleges in the UK, twelve were drawn from England, four from Scotland and one each from Wales and Northern Ireland. HEPS' aim was 'to establish a pioneering partnership group of Higher Education Institutions (HEIs) that are seen to be achieving their strategic objectives through positive engagement with the sustainable development agenda, and to generate the transferable tools, guidance and inspiration that will encourage the rest of the sector to do likewise'.

HEPS now believes that the 18 universities and colleges they have been working with are now delivering excellent education in a way that boosts sustainable development because all are now developing green buildings, cutting emissions and improving the curriculum. In HEPS' view, universities and colleges play three roles in society, as:

> Institutions that form and inform leaders and decision-makers of today and tomorrow through teaching and research agendas.

$>$ Managers of major businesses where prudent use of resources not only saves money but safeguards reputations.

$>$ Important bodies in the local communities and regional development- as employer, purchaser, service user and provider.

The above three roles emanate from the speech delivered by D. L. Johnston, the then Principal and Vice-Chancellor of McGill University, Canada and Member of the International Association of Universities (IAU) Administrative Board of November 1993 at the IAU $9^{\text {th }}$ Round Table, Kyoto, Japan.

In order to ensure commitment to active engagement in the partnership, agreement was reached at vice-chancellor/principal level. The work of HEPS is delivered through three types of activities:

$>$ Individual work programmes tailored to the institution's priorities.

$>$ Partnership wide capacity building activities covering areas of interest to all partners (e.g. purchasing, travel planning, finance, resource management and communicating for sustainability). 
$>$ Sustainability reporting: developing a framework and process for tracking progress and communicating an institution's contribution towards sustainable development.

Source: Accounting for Sustainability (2003) p. 7.

\section{The research study}

The study seeks to contribute to knowledge in the field of corporate social responsibility in relation to a group of not-for-profit social entities using higher education institutions in the UK. Institutions of higher education are classified in the UK as not-for-profit or public sector corporate entities. It was felt that the results of such research would enrich people's understanding of what these institutions are doing about social responsibility and how they go about discharging their responsibilities to societies both far and near.

To gather the information needed for the study, letters were sent to one hundred and twenty-one (121) Vice Chancellors/Principals/Chief Executives of all universities and colleges of higher education in the UK - 92 in England, 14 in Scotland, 2 in Northern Ireland and 13 in Wales. The letter briefly explained what the study was about and asked the Vice Chancellor or Principal or Chief Executive to 'explain in as much detail as possible what he/she considers to be the social responsibilities of his/her university/college and how the university's management goes about discharging these responsibilities'. A conscious decision was made not to send reminders to non-responding VCs for two reasons. To ensure that no one was coerced into participating in the study since these individuals are generally recognised as extremely busy people and secondly to establish whether being socially responsible is now part of normal day to day practice of these institutions of higher education.

Thirty-three (33) replies were received from 33 universities and colleges. Replies from these institutions have been analysed and grouped according to their themes and commonalities. A conscious decision was made not to name or ascribe any piece of information to any university. This was to ensure anonymity and to ensure that non responding universities were not disadvantaged in any way as a result of the study. Out of the 33 replies received, 10 universities told stated that they were unwilling to provide the required information, giving different reasons for their decision.

Twenty-three higher education institutions from the four UK countries have participated in the research and their names are: Birmingham, Brighton, Bradford, Buckingham, Derby, Hertfordshire, Hull, London Metropolitan, London South Bank, Loughborough, Luton, King's College London, Imperial College London, Manchester, Nottingham, Roehampton, Royal College of Music London, Wolverhampton, Queen's Belfast, Cardiff, Aberdeen, Glasgow and Glasgow Caledonia.

The list above indicates the following response rates from HE institutions in the four UK countries England 19.57\%, Northern Ireland 50\%, Scotland 21.43\% and Wales $7.69 \%$. It also indicates that $61 \%$ of these responding universities are pre-1992 universities and 39\% are post-1992 universities. 
The aspects that these institutions consider to be their corporate social responsibility have been grouped under different headings; some of these aspects are common to them whilst a few are unique to certain universities. The following are the general headings:

$>$ Widening Participation

$>$ Developing and communicating performance on sustainable developments

$>$ Contributing both to national and international systems of university education

$>$ Managing the economic, social and environmental impacts of their activities

$>$ Take into account the interests of all stakeholders and act as good citizens

$>$ Joining Business in the Community (BitC) as an initial step

$>$ Responding to social needs in terms of Education and Innovation

$>$ Engagement with Corporate bodies through Staff

$>$ Providing a more effective Community Service

$>$ Challenging, Inspiring and Supporting Students to Grow

$>$ Sustaining and adding value to country's culture, economy and the natural environment

$>$ To manage and govern itself with responsibility and sensitivity

\section{The implications of the findings from the research}

The findings of this research study have clearly demonstrated that some institutions of higher education in the UK are still not explicit of what their responsibilities to society are. Some universities are still a few years behind others when it comes to demonstrating their social responsibilities to stakeholders. A document in place on the organisation's policies or frameworks on CSR would have sufficed. We received excuses such as -'we are too busy' 'we receive too many requests similar to this' 'you are not a big organisation' etc, perhaps they do not have any policy or documents to give callers on their social responsibilities. It is hoped that this study would serve as a wake-up call to any institution that falls within this category. Being socially responsible is now no longer an option, but a moral obligation, which must be fulfilled by all responsible corporate entities. CSR in higher education institutions is not about teaching and researching, society has accepted that these institutions are very proficient at doing these. It is about taking cognisance of the impact of their operations on their stakeholders, the environment and the world at large. Except they can demonstrate beyond reasonable doubts that being socially responsible is equally important to them and is aware of what this entails; they have a very high mountain to climb. The industry they operate in is rapidly changing; they must rise up to all the challenges that accompany the inevitable change. They can do it, because they are really doing a good job in their core business, all they need to do is find the time to do what is required. 


\section{Conclusion}

This study confirms that many UK institutions of higher education are taking the issue of corporate social responsibility and sustainable developments seriously. Many, as far as one can see are socially responsible; providing non-sensitive information to members of the public who need this for whatever purposes actually demonstrates a very high degree of responsibility. Not many of these institutions fall under this category. The industry is changing. They now have to deal with a host of stakeholders, clients and competitors included. Like their counterparts in the profit seeking sector; which have since realised that in order to compete effectively in modern markets; to out-perform their counterparts in their industry they need to have some competitive edge, CSR could perhaps provide this for them. They can no longer continue to just conform to the basic rules of society; in fact many of those basic rules are changing too and would hopefully continue to change. They must go well beyond meeting society's basic expectations in other words, conduct themselves in a socially desirable manner. Unless, these institutions re-define their corporate strategies many of them are unlikely to survive and prosper in the $21^{\text {st }}$ century as the industry becomes more competitive.

Many of these institutions have realised that they cannot only be involved with impacting educational knowledge and giving paper qualifications - their social responsibility has extended well beyond that boundary, they must also be seen to be actively involved in helping to solve social problems which fall within their areas of confine. Being socially responsible, appears to be the way forward not just for profit seeking corporate entities but also for those entities in the not for profit sector of the economy.

\section{References}

[1] Belkaoui, A. (1980), 'The impact of socio-economic accounting statements on the investment decision: an empirical study', Accounting, Organisations and Society Vol. 5 No. 3 pp. 263-283.

[2] Buzby, S. L. and Falk, H., (1979), 'Demand for social responsibility information by university investors', The accounting Review Vol. 54 No. 1 pp. 23-37.

[3] Carroll, A. B. (1989), Business and Society: Ethics and Stakeholder Management, South-Western, Cincinnati, $\mathrm{OH}$.

[4] Clarkson, M. B. E. (1995), 'A stakeholder framework for analysing and evaluating corporate social performance' Academy of Management Review, Vol. 20 pp. $92-117$.

[5] Crowther, D. (2003), 'Corporate social reporting: genuine action or window dressing' In Crowther, D. and Rayman-Bacchus, L. (Eds.), Perspectives on Corporate Social Responsibility, Ashgate, Aldershot, pp.140-160.

[6] Elkington, J. (1997), Cannibals with Forks: The Triple Bottom Line of $21^{\text {st }}$ Century Business, Capstone, Oxford.

[7] Fien, J. (2002), 'Advancing sustainability in higher education: Issues and opportunities for research' International Journal of Sustainability in Higher Education, Vol. 3 No. 3, pp. 243-253. 
[8] Freeman, R. E. (1984), Strategic Management: A Stakeholder, Pitman Publishing, Boston, Mass.

[9] Friedman, M. (1970), 'The social responsibility of business is to increase its profits' The New York Times Magazine, September 13.

[10] Gray, R., Walters, D., Bebbington, J, and Thomson, I. (1995), The greening of enterprise: an exploration of the role of environmental accounting and environmental accountants in organisational change, Critical Perspectives on Accounting, Vol. 6 No. 3 pp 211-239.

[11] Gray, R., Owen, D. and Adams, C. (1996), 'Accounting and Accountability, Changes and Challenges in Corporate Social and Environmental Reporting', Prentice-Hall, Harlow.

[12] Hart, S. L., (1997), 'Beyond greening: strategies for a sustainable world' Harvard Business Review, Vol. 75 No. 1 pp. 67-76.

[13] Higher Education Partnership for Sustainability, (2003), 'Accounting for Sustainability: Guidance for Higher Education Institutions', November, pp. 7.

[14] Holmes, S. L. (1976), 'Executive perceptions of corporate social responsibility', Business Horizons, Vol. 19 pp34-40.

[15] Holt, D. (2003), 'The role and impact of the business school curriculum in shaping environmental education at Middlesex University', International Journal of Sustainability in Higher Education, Vol. 4 No. 4, pp. 324-343.

[16] Idowu, S. O. and Towler, B. A. (2004), 'A comparative study of the contents of corporate social responsibility reports of UK companies' Management of Environmental Quality: An International Journal, Vol. 15 No. 4 pp. $420-437$.

[17] Idowu, S. O. and Papasolomou, I. (2007), 'Are the corporate social responsibility matters based on good intentions or false pretences? An empirical study of the motivations behind the issuing of corporate social responsibility reports by UK companies', Corporate Governance: The International Journal of Business in Society, Vol. 7 No 2 pp. 136-147.

[18] International Finance Corporation www.ifc.org

[19] Jensen, M. C. and Meckling, W. H. (1976), 'The theory of the firm: managerial behaviour, agency cost and ownership structure', Journal of Financial Economics, Vol. 3 No. 4 pp. 305-360.

[20] Lindblom, C. K. (1994), 'The implications of organisational legitimacy for corporate social performance and disclosure' Critical perspectives on Accounting Conference, New York.

[21] Mahapatra, S. (1984), 'Investor reaction to corporate social accounting' Journal of business, finance and accounting, Vol. 11 No. 1 pp. 29-40.

[22] Maltby, J. (2004), 'Hadfield Ltd: its annual general meetings 1903-1939 and their relevance for contemporary corporate social reporting' The British Accounting Review, Vol. 36 No. 4 pp. 415-439.

[23] Noeke, J. (2000), 'Environmental management systems for universities - A case study' International Journal of Sustainability in Higher Education, Vol. 1 No. 3, pp. 237-251.

[24] Norris, G. and O'Dwyer, B. (2004), 'Motivating socially responsive decision making: the operation of management controls in a socially 
responsive organisation' The British Accounting Review, Vol. 36 No. 2 pp. 173-196.

[25] Ricart, J. E., Rodriguez, M. A. and Sanchez, P. (2005), 'Sustainability in the boardroom: An Empirical examination of Dow Jones Sustainability World Index leaders' Corporate Governance: The International Journal of Business in Society, Vol. 5, No.3 pp. 24-41.

[26] Senge, P. M. and Carstedt, G. (2001), 'Innovating our way to the next industrial revolution', Sloan Management Review, Vol. 42 No. 2 pp. 24-38.

[27] Spicer, B. H. (1978), 'Investors, corporate social performance and information disclosure: an empirical study', The accounting review, Vol. 53 No. 1 pp. 94-111.

[28] Suchman, M. C. (1995), 'Managing legitimacy: strategic and institutional approaches' Academy of Management Review Vol. 20 pp. 571-610.

[29] van Weenen, H. (2000), 'Towards a vision of a sustainable university', International Journal of Sustainability in Higher Education, Vol. 1 No. 1 pp. 20-34.

[30] Vogl, A. J. (2003) 'Does it pay to be good? Across the Board, New York, Jan/Feb. pp. 16-23.

[31] Wals, A. E. J. and Jickling, B. (2002), "Sustainability" in higher education: From doublethink and newspeak to critical thinking and meaningful learning', International Journal of Sustainability in Higher Education, Vol. 3 No. 3, pp. 221-232.

[32] Wright, T. S. A. (2002), 'Definitions and frameworks for environmental sustainability in higher education' International Journal of Sustainability in Higher Education, Vol. 3 No. 3, pp. 203-220. 